\title{
Encephalitis in Course of Mononucleosis- A Case Report
}

\author{
Józefczuk Jan ${ }^{1 *}$, Kołeczek Małgorzta ${ }^{2}$, Kotarski Józef ${ }^{1}$, Lampart Urszula ${ }^{1}$ and Czarnecki Rafał ${ }^{1}$ \\ ${ }^{1}$ The Paediatric Ward with the Paediatric Cardiology Unit-Specialist Hospital of the Holy Spirit in Sandomierz, Poland \\ ${ }^{2}$ The Radiology Laboratory- Specialist Hospital of the Holy Spirit in Sandomierz, Poland
}

Submission: September 13, 2017; Published: October 20, 2017

*Corresponding author: Józefczuk Jan, The Paediatric Ward with the Paediatric Cardiology Unit- Specialist Hospital of The Holy Spirit in Sandomierz, ul. Schinzla 13, 27-600 Sandomierz, Poland, Tel: +48608080282; Fax: +48158323575; Email: janjose@poczta.onet.pl

Abstract

Mononucleosis is an acute, contagious viral disease characterized by hyperthermia, enlarged tonsils and surrounding lymphoid tissue and hepatosplenomegaly. We present a case of 17-year-old boy with a typical mononucleosis and a rare complication in the form of oligosymptomatic encephalitis. Rapid and accurate diagnosis, and immediate treatment including acyclovir and other drugs, resulted in full recovery.

Keywords: Epstein-Baar virus; Mononucleosis; Encephalitis; Acyclovir

\section{Introduction}

Epstein-Barr virus (EBV) is a virus belonging to the herpes genus (along with other, including herpes simplex and cytomegalowirus). It is one of the most common viruses in the human organism. In majority of people infection with the virus is asymptomatic. The virus is named after Michael Epstein and Yvonne Barr, who discovered it in 1964. Epstein-Barr virus is able to cause infectious mononucleosis. The disease develops if the first contact with the virus takes place during the puberty period or later [1].

Epstein-Baar virus infection causing infectious mononucleosis rarely leads to encephalitis [2].

Encephalitis is an inflammatory condition of cerebral tissues resulting from a direct infection of the brain and/or as a result of immunological reactions leading to dysfunction of the central nervous system (CNS).

It is usually an acute disease, and it may be local or disseminated.

The most common causes of acute encephalitis are viruses: Herpes (with Epstein-Barr virus), enteroviruses, measles, mumps, influenza and parainfluenza viruses, and viruses belonging to the Flaviridae family [3].

A 17-y.o. male, active sportsman, who suffered only minor infections in the past, was admitted to the Ward because of fatique, episodes of vomiting, somnolence and a slight psychomotor sluggishness.

These alarming symptoms developed in course of a 5-day long, untreated infection of the upper respiratory tract. Physical examination upon admittance, revealed exudative pharyngitis, submandibular and cervical lymphadenopathy. Ultrasound examination of the abdomen showed enlargement of the spleen.

\section{Results}

The neurological examination revealed: muscular tonus, muscular strength and deep reflexes in upper and lower extremities normal and symmetrical. Optic nerves: pupils equal, round, palpebral fissures equal, normal reaction to light, no nystagmus. Other cranial nerves also demonstrated no abnormalities. Slight diasturbance of balance, a positive Romberg's test, and a positive finger-to-nose test. The Babinski reflex was bilaterally negative. There were no meningeal signs present.

In ophthalmological examination: optic discs were pale-pink, flat, with clear outlines, normal course of blood vessels.

Clinical laboratory tests revealed that complete blood cell count was within normal range with a clear prevalence of lymphocytes in peripheral blood smear, and low values of inflammation markers (ESR: 2 CRP: $1.6 \mathrm{mg} / \mathrm{L}$ ), Patient had also developed transaminitis. 
Lumbar puncture was conducted. Cerebrospinal fluid was colourless, clear, with a slightly increased cytosis, normal protein content and negative Nonne-Appelt's and Pandy's reactions (cytosis - 50/3; protein - $27 \mathrm{mg} / 100$, glucose - $3.28 \mathrm{mmol} / \mathrm{L}$, chlorides $-124 \mathrm{mmol} / \mathrm{L}$; reactions: Nonne-Appelt's and Pandy's (-) negative. Sediment: leuococytes - 1-2 in lpf, RBCs - in lpf)

\section{Results of functional tests of the brain and of imaging diagnostics}

Electroencephalography (EEG) (8th day of the disease): Record taken in waking state, somnolence and physiological sleep. In waking state the basic alpha function $8 \mathrm{~Hz}$ with the amplitude up to $30 \mathrm{mcv}$, regular. The record was spatially variable. Signs of somnolence visible in the record. The eyes-closed and eyesopen reaction poorly marked. Photo-stimulation with no effect on the record. The record taken during the physiological sleep with correctly marked bioelectric features. Sleep spindles and $\mathrm{K}$ complexes visible. Photo-stimulation during sleep had no effect on the bioelectric brain activity.Conclusion: The record taken in waking state at the border of the normal range (slightly slower in relation to the patient's age), during sleep the record was normal, with no paroxysmal features.

EEG (20th day of the disease): The record taken in waking state. The basic alpha function $8-9 \mathrm{~Hz}$ with the amplitude up to $35 \mathrm{mcv}$, regular. The record was spatially variable. The eyes-closed and eyes-opened reaction present. Photo-stimulation with no effect on the record.Conclusion: The record within the normal range.

Magnetic resonance (MRI) of the brain with contrast (9th day of the disease): The review investigation performed in sequences SE T1, TSE T2, FLAIR and DWI and in SE T1 following the contrast administration, in transverse, frontal and sagittal planes, $3 \mathrm{~mm}$ and $5 \mathrm{~mm}$ thick slices.

Sequences FLAIR and DWI revealed patchy signal hyperintensities, visible bilaterally in posterior area of semioval centra and in deep areas of temporal lobes. Besides that the signal from the white and grey matter was normal. No pathological contrast enhancement was found after the contrast administration. The ventricular system was symmetrical, not dilated, and not dislocated.

No abnormalities were found in subarachnoid space. The MRI test result was unequivocal- a control imaging was recommended.

Magnetic resonance (MRI) of the brain with contrast (19th day of the disease): The review investigation performed in sequences SE T1, TSE T2, FLAIR and DWI and in SE T1 following the contrast administration, in transverse, frontal and sagittal planes, $3 \mathrm{~mm}$ and $5 \mathrm{~mm}$ thick slices.There were no hyperintense lesions, typical for the inflammatory process.No pathological contrast enhancement was found, following the contrast administration.

Serological studies: Anti-EBV antibodies were determined using the ELISA method in classes of IgM (antibodies against
Viral Capsid Antigen) and IgG (antibodies against Viral Nuclear Antigen).

Figure 1 Levels of antibodies VEB/VCA (mg/dl)

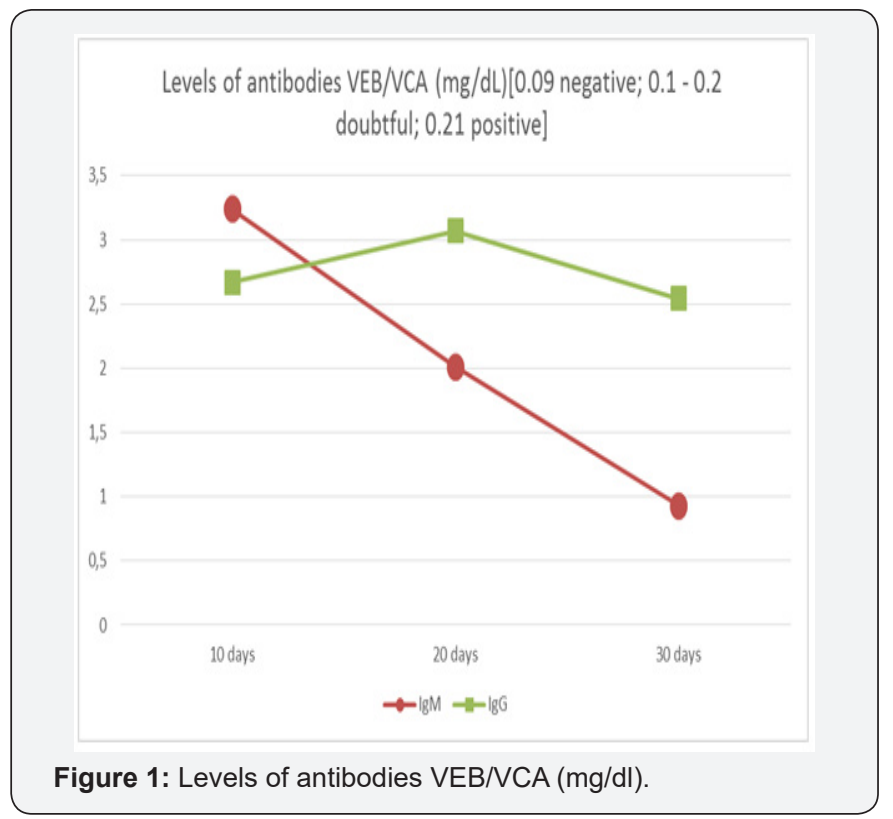

The number of EBV copies was determined using the PCR (Polymerase Chain Reaction) method.

Figure 2 Levels of EBV(x104 copies/mL)

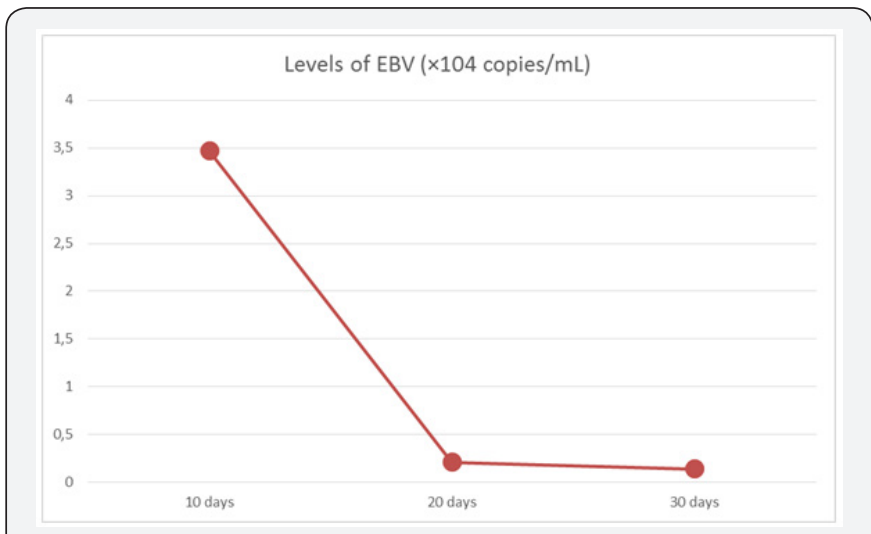

Figure 2: Levels of EBV(x104 copies/mL).

The clinical presentation, serological tests and radiological examinations of the patient were consistent with Epstein-Barr virus encephalitis.

\section{Discussion}

The introduction of an antioedematous and antiinflammatory treatment and administration of acyclovir, during the hospitalisation, resulted in gradual improvement of the patient's condition and clear improvement of his motor and mental activity.

The first EEG record demonstrated no paroxysmal features, and the record was slowed down in relation to the normal range for the age. In MRI scan, sequences FLAIR and DWI showed poorly distinguished areas of enhanced signal visible bilaterally 
in posterior area of semioval centres and in deep area of temporal lobes.

The control EEG and MRI of the brain were both normal.

At discharge, on the 21st day of the disease, the patient presented: independent walking on a slightly broadened base, decreased motor and mental activity.

On the 30th day of the disease the paediatric, neurological and psychological assessment demonstrated no abnormalities.

The following contributed in early diagnosis of encephalitis: medical history, assessment of the clinical condition, determination of anti-EBV IgM and IgG antibodies levels and the PCR analysis of EBV- DNA copies [4-7].

The relatively early diagnosis and introduced treatment resulted in complete recovery of the patient.

\section{Conflict of Interest}

The authors declare that there is no conflict of interest regarding the publication of this article.

\section{References}

1. Epstein MA, Achong BG, Barr YM (1964) Virus particles in cultured lymphoblasts from Burkitt's lymphoma. Lancet 1(7335): 702-703.

2. Cozad J (1996) Infectious mononucleosis. Nurse Pract 21(3): 14-16, 23, 27-28.

3. Jenson HB (2000) Acute complications of Epstein-Barr virus infectious mononucleosis. Curr Opin Pediatr 12(3): 263-268.

4. Tunkel AR, Glaser CA, Bloch KC, Sejvar JJ, Marra CM, et al. (2008) The management of encephalitis: clinical practice guidelines by the Infectious Diseases Society of America. Clin Infect Dis 47(3): 303-327.

5. Bloch KC, Glaser C (2007) Diagnostic approaches for patients with suspected encephalitis. Curr Infect Dis Rep 9(4): 315-322.

6. De Paschale M, Clerici P (2012) Serological diagnosis of Epstein-Barr virus infection: Problems and solutions. World J Virol 12(1): 31-43.

7. Gartzonika C, Vrioni G, Priavali E, Pappas G, Levidiotou S (2012) Utility of Real-Time PCR in the Diagnosis of Primary Epstein-Barr Virus Infection. J Med Microb Diagn 1: 118.

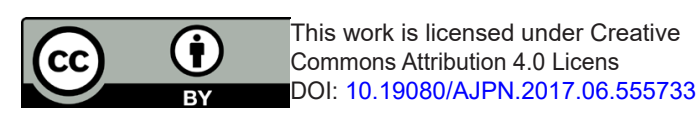

\section{Your next submission with Juniper Publishers will reach you the below assets}

- Quality Editorial service

- Swift Peer Review

- Reprints availability

- E-prints Service

- Manuscript Podcast for convenient understanding

- Global attainment for your research

- Manuscript accessibility in different formats

( Pdf, E-pub, Full Text, Audio)

- Unceasing customer service

Track the below URL for one-step submission https://juniperpublishers.com/online-submission.php 